\title{
Ketimpangan Faktor yang Mempengaruhi Kinerja: Kajian dalam Publikasi Ilmiah Terhadap Kinerja
}

\author{
Moh. Heru budi santoso', Mugi Harsono² \\ ${ }^{1}$ Universitas Islam Lamongan, Indonesia \\ ${ }^{2}$ Universitas Sebelas Maret, Surakarta, Indonesia \\ Email corresponding author: herubudi@unisla.ac.id/ mugiharsono_fe@staf.uns.ac.id
}

\begin{abstract}
ABSTRAK
Artikel ini bertujuan untuk mengungkap bahwasanya factor yang digunakan dalam menentukan kinerja masih sangat terbatas,hanya pada beberapa factor yang sudah umum.padahal menurut teori ada banyak sekai faktor oenentu kinerja yang dapat digunakan dan menjadi satu kesatuan.dan juga ditemukan dalam artikel terdahulu masih mencari hubungan secara langsung antar variable,tetapi jarang mencari peran variable mediasi serta menghubungkanya dengan teori dasar keperilakuan yang dibagi menjadi 3 hal utama.
\end{abstract}

Kata Kunci: The determining factor, performance

\section{PENDAHULUAN}

Sumber daya manusia adalah yang terpenting dan sangat menentukan dari seluruh sumber daya yang tersedia dalam suatu organisasi. Sumber daya manusia merupakan satu-satunya sumber daya yang memiliki akal, perasaan, keinginan, kemampuan, keterampilan, pengetahuan, dorongan, daya, dan karya (Hamali, 2016). Oleh sebab itu sumber daya manusia harus memiliki kompetensi dan kinerja tinggi demi kemajuan organisasi. Menurut Kaswan (2012) kinerja karyawan adalah yang mempengaruhi seberapa banyak atau besar mereka memberi kontribusi terhadap organisasi. Semakin besar karyawan memberikan kontribusi terhadap organisasi, semakin besar pula kinerja yang dihasilkan. Peningkatan kinerja karyawan akan membawa kemajuan bagi perusahaan, sehingga perlu adanya upaya-upaya untuk meningkatkan kinerja karyawan. Semakin banyak karyawan yang mempunyai kinerja tinggi, produktifitas perusahaan secara keseluruhan akan meningkat. Adapun factor-faktor yang dapat mempengaruhi kinerja karyawan Menurut Mangkunegara (2000), faktor yang mempengaruhi kinerja diantaranya motivasi, efektifitas dan efisiensi, wewenang, disiplin dan inisiatif. Selain pendapat tersebut Menurut Keith Davis dalam Anwar Prabu Mangkunegara (2007:13-14) terdapat beberapa faktor yang mempengaruhi pencapain kinerja, faktor -faktor tersebut dapat dijelaskan sebagai berikut: "Faktor yang mempengaruhi pencapaian kinerja adalah faktor kemampuan (ability) dan faktor motivasi (motivation), yang dirumuskan sebagai berikut: "Human Performance $=$ Ability + Motivation, Motivation $=$ Atitude + Situation, Ability $=$ Knowledge+Skill”.

Tetapi permasalahan dan fenomena yang terjadi pada penelitian kebanyakan berfokus pada factor motivasi dan budaya organisasi saja, sedangkan factor yang lain jarang sekali digunakan oleh karena itu terjadi ketimpangan dalam pengunaan pemilihan factor hal ini ditemukan dari hasil mapping penelitian terdahulu yang telah melakukan riset berhubungan dengan kinerja karyawan.

Mathis \& Jackson (2016) mendefinisikan kinerja pegawai sebagai besaran kontribusi yang dilakukan oleh pegawai yang diidentifikasi melalui kuantitas dan kualitas output, jangka waktu output, kehadiran ditempat kerja dan sikap kooperatif. Sementara Mangkunegara (2016) 
lebih spesifik menjelaskan bahwa kinerja pegawai merupakan perbandingan antara hasil kerja dan standar kerja yang telah ditetapkan. Standar kerja merupakan standar pelayanan minimal yang telah ditetapkan oleh kementerian atau lembaga berwenang lainnya dengan tujuan sebagai acuan standar pelayanan pegawai publik terhadap masyarakat pada umumnya. Selain itu juga dijelaskan jika kinerja pegawai secara ringkas dipengaruhi oleh dua faktor utama, yaitu motivasi kerja dan budaya organisasi.

Motivasi kerja bagi pegawai merupakan hal yang penting, dengan motivasi yang tepat, para pegawai akan terdorong untuk bekerja semaksimal mungkin dalam melaksanakan tugasnya. Hal ini karena pegawai tersebut akan meyakini bahwa dengan keberhasilan organisasi dalam mencapai tujuannya, maka kepentingan setiap individu dalam sebuah organisasi akan terpenuhi, Siagian (2016). Sementara itu, budaya organisasi diartikan sebagai sistem yang memuat tentang nilai-nilai yang dianut dan disepakati oleh anggota organisasi melalui penataan hak, wewenang dan tanggungjawab dalam rangka mewujudkan visi dan misi organisasi. Dengan menentukan visi dan misi, organisasi memiliki strategi bersama untuk mewujudkan kinerja organisasi yang berkualitas, berfokus pada peningkatan kualitas pelayanan secara terus menerus. Hal itu dilakukan dengan cara membangun suatu lingkungan kerja yang memungkinkan para pegawai mentransformasikan potensinya menjadi kinerja organisasi yang dihargai tinggi. Dengan demikian, misi dan filosofi dapat dikatakan sebagai elemen kunci dalam membentuk dan menumbuhkan budaya organisasi, yang digunakan sebagai alat untuk mencapai tujuan (Nurcahyono, 2015).

Teori motivasi menjelaskan faktor yang mempengaruhi seorang manusia memiliki motivasi untuk melakukan pekerjaan dan mencapai tujuan dalam pekerjaan. Siagian (2017) mengemukakan dalam pengembangan konsep motivasi, telah berkembang teori-teori motivasi yang dapat memberikan penjelasan mengenai motivasi kerja para anggota organisasi, Adapun teori-teorimotivasi tersebut yaitu: Tingkat kebutuhan yang paling rendah dalam hirarki ini dikenal sebagai kebutuhan fisiologis dan yang tertinggi adalah kebutuhan realisasi diri. Hirarki kebutuhan tersebut adalah sebagai berikut:

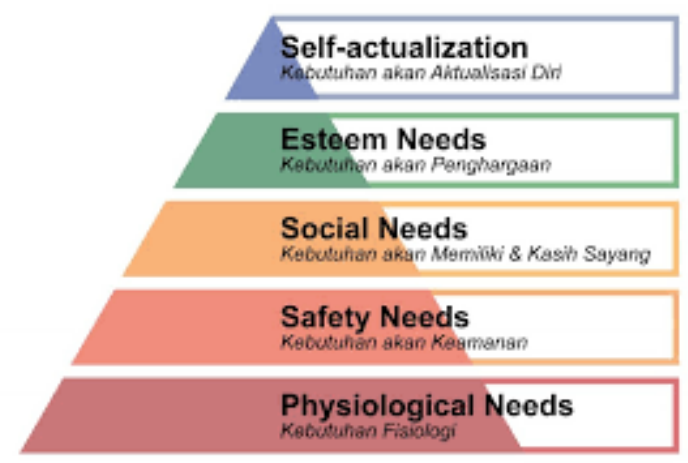

Gambar 1. Hirarki Kebutuhan Maslow Sumber: Hasibuan (2012).

Motivasi kerja tiap individu tidak sama, maka dari itu hal ini harus diperhatikan oleh atasab untuk selalu mengupayakan pegawainya agar memiliki motivasi kerja yang tinggi karena motivasi kerja yang tinggi sangat penting untuk meningkatkan kinerja pegawai. Menurut Gagne (2005) dan Tuan (2011), berpendapat bahwa motivasi kerja karyawan merupakan hal penting yang harus diperhatikan para pimpinan perusahaan, karena motivasi kerja berpengaruh besar dalam meningkatkan kinerja karyawan.

Kinerja merupakan suatu hasil kerja yang dicapai oleh seseorang dalam melaksanakan tugas yang dibebankan kepadanya berdasarkan atas kecakapan, pengalaman, dan kesungguhan, serta waktu (Hasibuan, 2002). Dalam mengukur kinerja menggunakan 3 dimensi dan beberapa indikator diantaranya, 1) dimensi hasil kerja dengan indikator kuantitas, kualitas, dan efisiensi; 
2) dimensi perilaku kerja dengan indikator inisiatif, disiplin kerja dan ketelitian; serta 3) dimensi kematangan pribadi dengan indikator kejujuran dan kreativitas (Wirawan, 2009:80).

Rendahnya kinerja pegawai diduga disebabkan oleh rendahnya motivasi pegawai. Motivasi sebagai daya penggerak dari dalam individu untuk melakukan pekerjaan tertentu guna mencapai tujuan yang diinginkan (Busro, 2018:51). Adapun dalam mengukur motivasi digunakan dimensi motivasi kerja menurut teori dua faktor Herzberg (Ivancevich, et al., 2002:154-155) yaitu faktor intrinsik (motivator) dan ekstrinsik (hygiene). Namun, dalam penelitian ini hanya menggunakan dimensi faktor intrinsik karena faktor ini dapat memacu seseorang untuk bekerja lebih baik dan bergairah serta membentuk motivasi yang kuat. Indikator motivasi faktor intrinsik menurut Herzberg yang dikutip oleh Luthans (2011:160) diantaranya keberhasilan (achievement), pengakuan (recognition), tanggung jawab (responsibility), pekerjaan itu sendiri (work it self), serta pengembangan (advancement).

\section{Mapping Riset Factor Yang Mempengaruhi Kinerja}

\begin{tabular}{|c|c|c|}
\hline Judul & Variabel faktor & Hasil \\
\hline $\begin{array}{l}\text { Faktor-faktor yang } \\
\text { mempengaruhi kinerja karyawan } \\
\text { pada } \\
\text { Pt surya cahaya inti denpasar } \\
\text { (I gusti gde oka pradnyana, } \\
\text { windry anggraini kase 2014) }\end{array}$ & $\begin{array}{l}\text { Tata ruang kantor } \\
\text { (x1) dan } \\
\text { lingkungan } \\
\text { Kerja fisik (x2) } \\
\text { kinerja karyawan } \\
\text { (y) }\end{array}$ & $\begin{array}{l}\text { Tata ruang kantor (x1) dan lingkungan } \\
\text { Kerja fisik (x2) secara parsial } \\
\text { berpengaruh positif dan signifikan } \\
\text { Terhadap kinerja karyawan (y) pada pt. } \\
\text { Surya cahaya inti-denpasar. } \\
\text { Tata ruang kantor (x1) dan lingkungan } \\
\text { Kerja fisik (x2) secara simultan } \\
\text { Berpengaruh positif dan signifikan } \\
\text { Terhadap kinerja karyawan (y) pada pt. } \\
\text { Surya cahaya inti-denpasar. }\end{array}$ \\
\hline $\begin{array}{l}\text { Analisis faktor yang } \\
\text { mempengaruhi } \\
\text { Kinerja karyawan (akhmad } \\
\text { nurrofi 2015) }\end{array}$ & $\begin{array}{l}\text { Disiplin } \\
\text { Kerja, Motivasi } \\
\text { Kerja dan kinerja }\end{array}$ & $\begin{array}{l}\text { Disiplin } \\
\text { Kerja berpengaruh positip dan } \\
\text { Signifikan terhadap kinerja } \\
\text { Karyawan } \\
\text { Motivasi } \\
\text { Kerja berpengaruh positif dan } \\
\text { Signifikan terhadap kinerja } \\
\text { Karyawan } \\
\text { Kompetensi berpengaruh positif } \\
\text { Dan signifikan terhadap kinerja } \\
\text { Karyawan. }\end{array}$ \\
\hline $\begin{array}{l}\text { analisis faktor-faktor yang } \\
\text { mempengaruhi kinerja karyawan } \\
\text { (studi kasus pada tiga } \\
\text { perusahaan fabrikasi lepas pantai } \\
\text { di batam dan karimun) } \\
\text { agustinus setyawan (2018) }\end{array}$ & $\begin{array}{l}\text { penghargaan } \\
\text { karyawan, } \\
\text { kepuasan } \\
\text { karyawan, perilaku } \\
\text { karyawan dan gaya } \\
\text { kepemimpinan } \\
\text { motivasi karyawan, } \\
\text { pengembangan } \\
\text { karyawan dan } \\
\text { lingkungan kerja }\end{array}$ & $\begin{array}{l}\text { hasil penelitian ini membuktikan bahwa } \\
\text { faktor penghargaan karyawan, kepuasan } \\
\text { karyawan, perilaku karyawan dan gaya } \\
\text { kepemimpinan mempunyai pengaruh } \\
\text { yang signifikan terhadap kinerja } \\
\text { karyawan. } \\
\text { faktor motivasi karyawan, } \\
\text { pengembangan karyawan dan lingkungan } \\
\text { kerja pada perusahaan yang bergerak di } \\
\text { bidang fabrikasi lepas pantai } \\
\text { pengaruhnya tidak signifikan terhadap } \\
\text { kinerja karyawan. }\end{array}$ \\
\hline
\end{tabular}




\begin{tabular}{|c|c|c|}
\hline 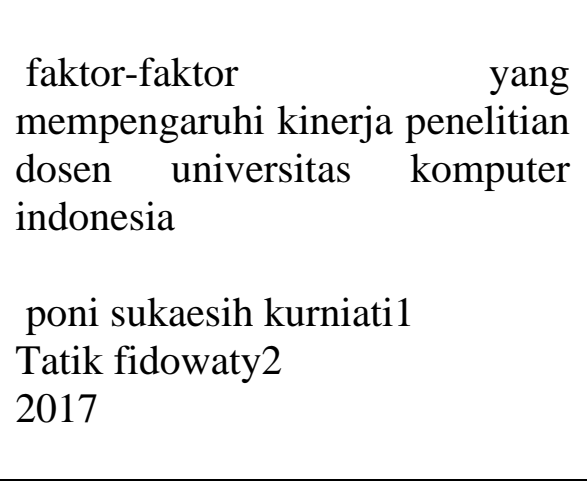 & $\begin{array}{l}\text { Dorongan individu } \\
\text { Dorongan } \\
\text { organisasi } \\
\text { Dorongan } \\
\text { manajemen } \\
\text { Kinerja }\end{array}$ & $\begin{array}{l}\text { hasil penelitian menunjukkan bahwa } \\
\text { kinerja penelitian dosen dipengaruhi oleh } \\
\text { kompetensi individu, dukungan } \\
\text { manajemen dan dukungan organisasi. } \\
\text { Secara simultan mempunyai pengaruh } \\
\text { yang signifikan terhadap kinerja dosen } \\
\text { yaitu sebesar } 32,5 \% \text { dan sisanya } \\
\text { dipengaruhi oleh faktor lain yang tidak } \\
\text { diteliti oleh peneliti. }\end{array}$ \\
\hline $\begin{array}{l}\text { Analisis faktor-faktor yang } \\
\text { mempengaruhi kinerja karyawan } \\
\text { pada perusahaan daerah di kota } \\
\text { medan raihanah daulay } 1 * \text {, efry } \\
\text { kurnia2, irvan maulana3 } \\
(2019)\end{array}$ & $\begin{array}{l}\text { komitmen } \\
\text { organisasi, } \\
\text { tanggungjawab } \\
\text { kerja, disiplin dan } \\
\text { kinerja }\end{array}$ & $\begin{array}{l}\text { Hasil penelitian ini dapat memperlihatkan } \\
\text { bahwa secara simultan komitmen } \\
\text { organisasi, tanggungjawab kerja, disiplin, } \\
\text { berpengaruh signifikan terhadap kinerja } \\
\text { karyawan pada perusahaan daerah di kota } \\
\text { medan }\end{array}$ \\
\hline $\begin{array}{l}\text { Faktor-faktor yang } \\
\text { mempengaruhi kinerja karyawan } \\
\text { pt. Mega mulia servindo di } \\
\text { makasar } \\
\text { Baharuddin latief (2012) }\end{array}$ & $\begin{array}{l}\text { Kompensasi, } \\
\text { motivasi dan } \\
\text { kinerja karyawan }\end{array}$ & $\begin{array}{l}\text { Faktor kompensasi dan motivasi } \\
\text { memiliki pengaruh yang positif dan } \\
\text { signifikan secara simultan terhadap } \\
\text { kinerja karyawan pt.mega mulia servindo } \\
\text { di makassar. }\end{array}$ \\
\hline $\begin{array}{l}\text { Faktor - faktor yang } \\
\text { mempengaruhi kinerja karyawan } \\
\text { di resturant alpha hotel } \\
\text { pekanbaru } \\
\text { Maria devita (2017) }\end{array}$ & $\begin{array}{l}\text { Individual } \\
\text {,organisasional dan } \\
\text { menejemen serta } \\
\text { kinerja }\end{array}$ & $\begin{array}{l}\text { The three factors above do affect } \\
\text { employee performance at alpha hotel } \\
\text { restaurant pekanbaru, that is individual } \\
\text { factor of organization factor and } \\
\text { management factor. }\end{array}$ \\
\hline $\begin{array}{l}\text { Analisis faktor-faktor yang } \\
\text { mempengaruhi kinerja pegawai } \\
\text { negeri sipil (pns) } \\
\text { Andarias patiran (2010) }\end{array}$ & $\begin{array}{l}\text { disiplin, } \\
\text { pendidikan, dan } \\
\text { motivasi } \\
\text { kinerja }\end{array}$ & $\begin{array}{l}\text { Terdapat hubungan yang sangat kuat } \\
\text { antara variabel disiplin, pendidikan, dan } \\
\text { motivasi terhadap variabel kinerja } \\
\text { pegawai. } \\
\text { Variabel tingkat pendidikan dan variabel } \\
\text { motivasi yang berpengaruh negatif dan } \\
\text { tidak signifikan pada tingkat signifikansi } \\
5 \%(0,05) \text {. Sedangkan variabel disiplin } \\
\text { berpengaruh positif terhadap kinerja } \\
\text { pegawai }\end{array}$ \\
\hline $\begin{array}{l}\text { Factor yang mempengaruhi } \\
\text { kinerja auditor } \\
\text { Elizabeth hanna dan friska } \\
\text { firnanti (2013) }\end{array}$ & $\begin{array}{l}\text { struktur } \\
\text { audit,ketidakjelasan } \\
\text { peran,budaya } \\
\text { organisasi,dan gaya } \\
\text { kepemimpinan } \\
\text { serta kinerja }\end{array}$ & $\begin{array}{l}\text { Hasil penelitian menunjukan bahwa } \\
\text { struktur audit,ketidakjelasan } \\
\text { peran,budaya organisasi,dan gaya } \\
\text { kepemimpinan berpengaruh terhadap } \\
\text { kinerja auditor.sedangkan konflik } \\
\text { peran,komitmen organisasi dan } \\
\text { pemahaman good governance tidak } \\
\text { mempengaruhi kinerja. }\end{array}$ \\
\hline
\end{tabular}

Berdasarkan hasil maping riset terdahulu diatas maka dapat dilihat bahwasanya pada riset yang mengunakan tema factor factor penentu kinerja karyawan didominasi oleh factor motovasi,disiplin ,lingkungan,gaya kepemimpinan dan lain sebagainya.hal ini menunjukan bahwasanya factor yang diambil mayoritas dibagi menjadi 2 faktor yaitu internal factor dan 
eksternal factor. Oleh karena itu masih terjadi ketimpangan terhadap factor factor lain yang belum dan jarang diungkap sebagaimana teori teori para ahli terdahulu.

Berdasarkan hasil mapping penelitian riset terdahulu maka dapat digambarkan sebagai berikut:

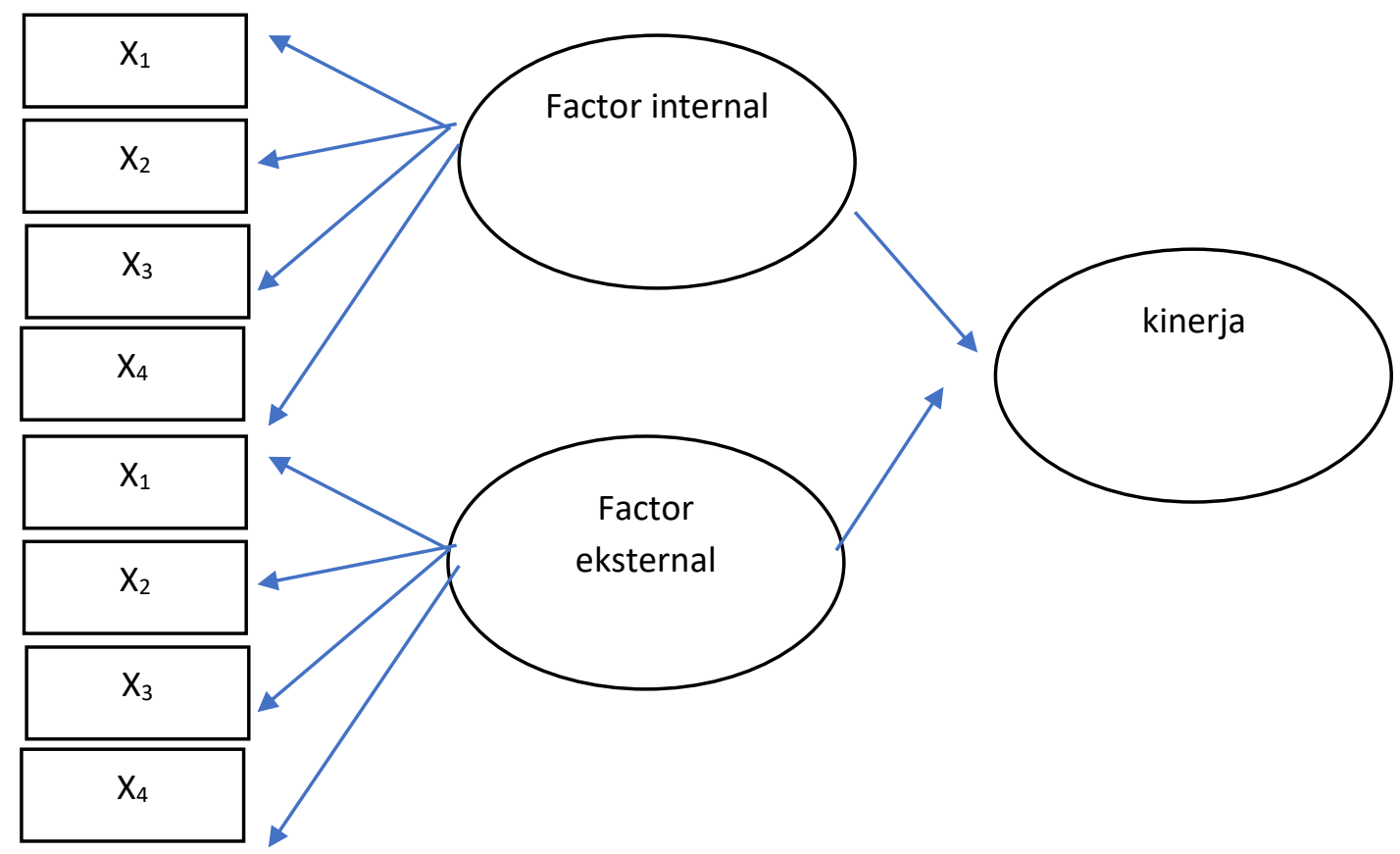

Gambar 1. model hubungan factor penentu kinerja

Jika dilihat dari kerangka model masing masing masih mengunakan hubungan variable secara langsung. bahwasanya penentu kinerja tidak hanya dipengaruhi langsung,tetapi juga dapat dipengaruhi secara tidak langsung,artinya ada peran variable lain yang memediasi atau memoderasi senhingga hubungan variable itu semakin kuat atau justru semakin lemah.karena pada hakekatnya pengukuran varibel yang berhubungan dengan sikap dan perilaku manusia tidak dapat dipisahkan dari teori dasar keperilakuan.oleh karena itu dapat diklasifikasikan dalam membentuk model penelitian yang berhungan langsung dengan perilaku individual. sebagai berikut:

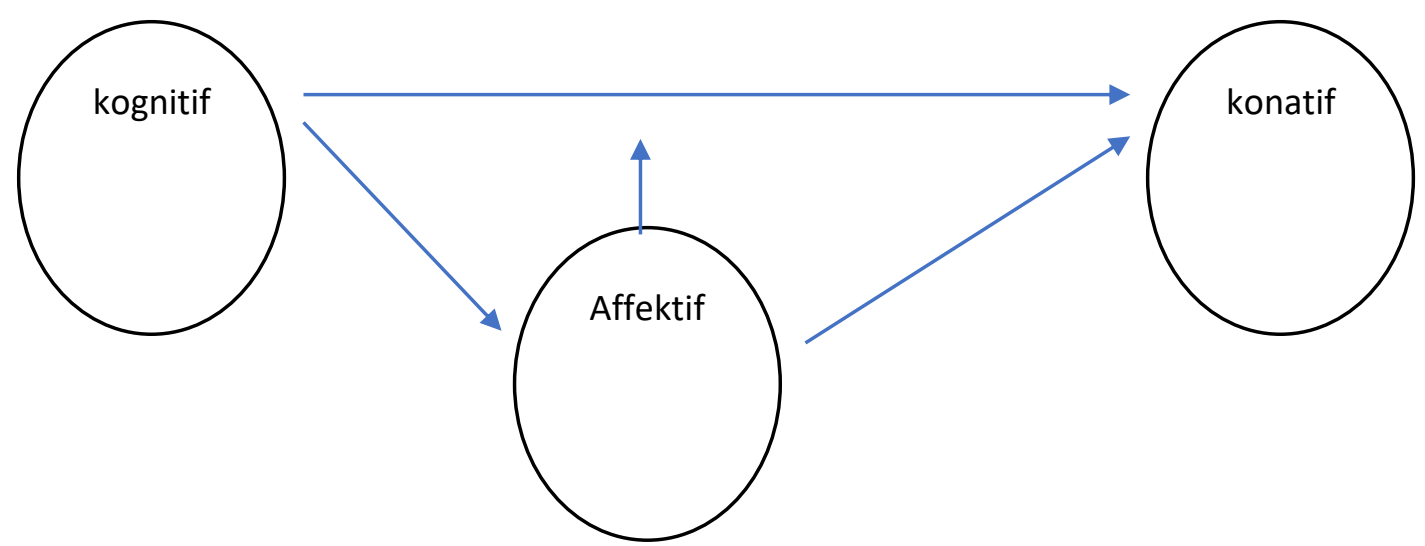

Gambar 2. model klaisifikasi keperilakuan

KESIMPULAN 
Berdasarkan pembahasan diatas maka dapat disimpulkan bahwasanya pengunaan factor dalam riset penentu kinerja karyawan masih sangat terbatas, artinya masih banyak variable variable yang belum diikutkan dalam rangkaian riset,hal itu dibuktikan dari hasil nilai $r$ square juga masih rendah,artinya masih banyak factor diluar yang mempengaruhi. Masih terjadi ketimpangan dalam riset yang berfokus pada beberapa factor saja,padahal berdasarkan teori para ahli ad banyak sekali variasi factor yang dapat digunakan untuk mengukur dari kinerja.selain itu masih juga dalam riset banyak digunakan untuk mencari hubungan secara langsung,padahal dalam riset ada hubungan yang sifatnya tidak langsung atau bahkan bias memperkuat atau memperlemah.

\section{DAFTAR PUSTAKA}

Agustinus Setyawan.(2018).Analisis Faktor-Faktor Yang Mempengaruhi Kinerja Karyawan (Studi Kasus Pada Tiga Perusahaan Fabrikasi Lepas Pantai Di Batam Dan Karimun).

Ahmad Tohardi. (2002). Pemahaman Praktis Manajemen Sumber Daya Manusia. Bandung: Universitas Tanjung Pura

Akhmad Nurrofi (2015)Analisis Faktor Yang Mempengaruhi Kinerja Karyawan.

Allison, B. J., Richard S.V., and Sean D. (2001), "Student Classroom and career success: The Rule of Organizational Citizenship Behavior", Journal of Education for Business, Vol.76 No.5 pp. 282-288.

Andarias Patiran (2010).Analisis Faktor-Faktor Yang Mempengaruhi Kinerja Pegawai Negeri Sipil (PNS).

Arikunto, Suharsimi. 2013. Prosedur Penelitian Suatu Pendekatan Praktik. Jakarta: PT. Rineka Cipta

Baharuddin Latief .(2012).Faktor-Faktor Yang Mempengaruhi Kinerja Karyawan PT. Mega Mulia Servindo Di Makasar.

Boston. Mayer. J.P and Allen.N.J, A Commitment in (1997), The Workplace: Theory Research and Application, Saga Publications, Inc., California. Noe.

Chye, H. and Meng, T. (1997), "Empirical investigation of the factors affecting SET results", International Journal of Educational Management, Vol. 11 No. 4, pp. 170-8. Davies, J.,

Daulay, Efry Kurnia , Irvan Maulana (2019).Analisis Faktor-Faktor Yang Mempengaruhi Kinerja Karyawan Pada Perusahaan Daerah Di Kota Medan Raihanah

Den Brok, P., Brekelmans, M., Levy, J. and Wubbels, T. (2002), "Diagnosing and improving the quality of teachers' interpersonal behaviour", International Journal of Educational Management, Vol. 16 No. 4, pp. 176-84.

Easton, G.S. and Jarrell, S.L. (1998), "The effects of total quality management on corporate performance: an empirical investigation", Journal of Business, Vol. 71, pp. 253-307.

Elizabeth Hanna Dan Friska Firnanti .(2013).Factor Yang Mempengaruhi Kinerja Auditor

Feist, J. and Gregory J. F. (2006), Theories of Personality, McGraw- Hill Education, Boston.

Fernandes, A.A.R, Budiantara, I.N, Otok, B.W., \& Suhartono. 2015. Spline Estimator for BiResponses and Multi-Predictors Nonparametric Regression Model in Case of Longitudinal Data, Journal of Mathematics and Statistics, Vol 11, No 2, 2015, pp. 61-69.

Greenberg, J., and Baron, R. A. (2000), Behavior in Organizations: Understanding and Managing the Human Side of Work, Prentice Hall International, New Jersey Higher (2010), Guidelines for faculty workload and evaluation of the tri dharma college

Hides, M.T. and Casey, S. (2001), "Leadership in higher education", Total Quality Management, Vol. 12 Nos 7/8, pp. 1025-30.

I gusti gde oka pradnyana , windry anggraini kase (2014).Faktor-faktor yang mempengaruhi kinerja karyawan pada Pt surya cahaya inti Denpasar. 
Kren,Leslie. (1992). Budgetary Participation and Managerial Performance: The Impact of Information and Environmental Volatility. The Accounting Review.

Luthans F. (1998), Organizational Behavior, McGraw-Hill International Edition, Management, and Organization Series Eighth Edition,

Mahmudi. (2005). Manajemen Kinerja Sektor Publik. Yogyakarta: UPP AMP YKPN.

Mangkunegara, Anwar Prabu. 2009. Manajemen Sumberdaya Manusia Perusahaan. Bandung: PT. Remaja Rosdakarya.

Maria Devita (2017).Faktor - Faktor Yang Mempengaruhi Kinerja Karyawan Di Resturant Alpha Hotel Pekanbaru

Nawawi, Hadari. 2011. Manajemen Sumber Daya Manusia Untuk Bisnis Yang Kompetitif. Yogyakarta: Gajah Mada University Press.

Organ, D.W. (1998), OCB: The Good Soldier Syndrome, Lexington Books, Lexington.

Organ, Dennis W., et. al. (2006), Organizational Citizenship Behavior.Its Nature, antecedents, and Consequences, Sage Publications, Inc, California.

Podsakoff, P. M., MacKenzie, S. B., Paine, J. B., and Bachrach, D. G. (2000), “Organizatinal Citizenship Behavior: A critical review of the theorical and empirical literature and suggestions for future research", Journal of Management, No.26, pp.513-563.

Poni Sukaesih Kurniati,Tatik Fidowaty (2017)Faktor-Faktor Yang Mempengaruhi Kinerja Penelitian Dosen Universitas Komputer Indonesia

Pratheepkanth, Puwanenthiren. (2011). Reward System and Its Impact on Employee Motivation in Commercial Bank of Sri Lanka Plc, in Jaffna District. Global Journal of Management and Business Research, Volume 11 Issue 4 Version 1.0 March 2011

Pruijt,Hans. 2003. Performance and Quality of Work Life, Journal of Organizational Change Management. Vol. 13, hal. 389-400.

Syairozi, M. I. (2017). Prospek Pengembangan Ilmu Ekonomi Islam di Indonesia dalam Prespektif Filsafat Ilmu (Sebuah Kajian Epistemik). JPIM (Jurnal Penelitian Ilmu Manajemen), 2(1), 16-Halaman. 